\title{
Research on Influence of Audit Informatization on Social Audit
}

\author{
Wei $\mathrm{Li}^{1, \mathrm{a} *}$,Fenglian Zhou ${ }^{2, \mathrm{~b}}$ and HeFeng Zou ${ }^{3, \mathrm{c}}$ \\ ${ }^{1}$ Chengdu Neusoft University, Sichuan \\ ${ }^{2}$ Chengdu Neusoft University, Sichuan \\ ${ }^{3}$ Chengdu Neusoft University, Sichuan

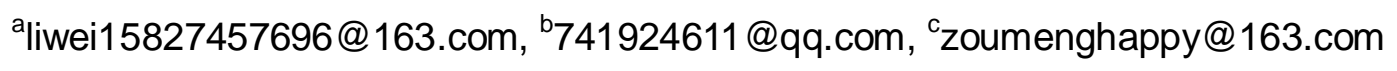 \\ * The corresponding author
}

Keywords: Informatization; Audit informationization; Social audit; Influence

\begin{abstract}
Informatization is promoting China's development of economic. As an independent economic supervision activity, social audit is also affected by informationization. It has played a catalytic role on the sound development of social audits to research on the informatization impact of social auditing. This article studies the impact of audit informationization on social audit through literature research method, and it finds that its positive effects include improving audit efficiency, changing audit methods, and promoting auditing technology change, that its negative effects include increasing information security risks and increasing audit risk. In response to the above negative effects, it can strengthen the construction of network security, improve the audit-related system construction, and cultivate complex talents for social audit to deal with.
\end{abstract}

\section{Introduction}

Certified Public Accountant Industry has attached great importance to informatization construction during "Twelfth Five-Year Plan" period and has defined industry informationization as an industry development strategy. The Chinese Institute of Certified Public Accountants issued the document of "The Overall Plan of Industrial Informatization Construction" and related to guide the CPA industry informatization construction. The construction of audit informationization has played a horn since then. The CACPA has issued a number of documents to guide the construction of informatization, to deepen the implementation of CPA industry informatization strategy, to realize the leap-forward development of the industry led by information technology.

Auditing is an independent economic supervision activity. It can be divided into three types: government audit, social audit and internal audit according to the nature of the auditing execution entity .Social audit is also called CPA audit or independent audit. It refers to the activities are entrusted in accordance with the law by certified public accountants who perform business independently to provide professional services for the society.

Informationization is a kind of technology which is based on the modern communication, network and database technology, which summarizes all the elements of the research object to the database for certain people to live, work, study and combine with all kinds of human behavior.

Information originates from Japan in the 60's, and has been widely used in western society in the 70's. Informationization in China started late, the first national informationization work meeting was held in 1997, and informatization is developing rapidly in China since then. Since the 18th national congress of the communist party of China, informatization has been upgraded to the national strategic level. Auditing informatization refers to the information system which makes full use of information technology and application furtherly in audit work.

\section{Information Status of Social Audit}

With the extensive use of information technology, the informatization construction of social audit has achieved certain results, which are reflected in the aspects of facilities construction, human 
resources guarantee and system construction.

The Construction of Supporting Facilities. With the extensive promotion of big data and artificial functions in China, Chinese enterprises generally have good hardware conditions, CPA firms are even more so. However, as a service industry, social auditing attaches more importance to the construction of software facilities. All the firms engaged in social auditing use auditing software. However, there is no unified auditing software among social audit institutions.

Currently, the international "big four accounting firms" have a large market share in China, which use customized auditing software, including Aura, AS/2, Eaudit, and so on. As their core business is different, it's normal to use different auditing methods. The auditing software used in accounting firm of domestic is basically domestic auditing software, such as Ding cigna, Zhongpu audit software, E auditing software. These software systems are less interconnected and less functional.

Supply and Demand of Human Resource of Audit Informatization. Under the information background, we can see that social recruitment requires the applicant having computer knowledge. Candidates with strong computer skills are preferred under the same conditions, social audit is no exception. In the context of informatization, social auditing needs talents in auditing informatization who should be compound talents with financial auditing knowledge, auditing information system and big data skills. Ministry of industry launched the examination of Certified Information System Auditor in China in 2016, which has promoted the identification of professional competence of employees. But as another important test of social audit talent identification, the CPA examination does not involve information capability identification standard too much. At present, the information knowledge of social auditors is limited to Excel operation simply. There is a shortage of interdisciplinary talents who master finance and information technology. Therefore, there is little talent supply with auditing informationization level, and the supply is far less than the demand.

Institutional Guarantee. Social audit informatization started late in our country, and the system guarantee is not perfect. The Chinese Institute of Certified Public Accountants (CICPA) has published the list of "top 100 information of annual comprehensive evaluation of accounting firms" of the previous year every year since 2003. From 2003 to 2013, the ranking of firms was mainly based on annual business income, and the highest came first. This principle of sequencing learns from the international practice at that time. CICPA publishes the list based on comprehensive evaluation score which is revised newly from 2014. The evaluation index includes "information technology", which evaluates the information technology of firms from qualitative and quantitative aspects. Specific indicators are shown in table 1 below.

Table 1 Evaluation index system of Information technology in social auditing industry

\begin{tabular}{|c|c|c|}
\hline & Indicators of Information Technology & $\begin{array}{l}\text { Method of Filling } \\
\text { out }\end{array}$ \\
\hline \multirow[t]{5}{*}{$\begin{array}{l}\text { Qualitative } \\
\text { Indicators }\end{array}$} & $\begin{array}{l}\text { (1)Whether to set up an support department of } \\
\text { information technology }\end{array}$ & \multirow{5}{*}{$\begin{array}{l}\text { Fill in the relevant } \\
\text { information } \\
\text { according to the } \\
\text { existence of the firm } \\
\text { itself. }\end{array}$} \\
\hline & (2)Whether to use audit software & \\
\hline & (3)Whether to use internal management software & \\
\hline & (4)Whether to establish a portal website & \\
\hline & $\begin{array}{l}\text { (5)Whether to use the national unified technical support } \\
\text { platform }\end{array}$ & \\
\hline \multirow{3}{*}{$\begin{array}{l}\text { Quantitative } \\
\text { Indicators }\end{array}$} & (1)Development fee of auditing software & \multirow{3}{*}{$\begin{array}{l}\text { Generated according } \\
\text { to the original data } \\
\text { automatically. }\end{array}$} \\
\hline & (2)Development fee of management information system & \\
\hline & (3)Others & \\
\hline
\end{tabular}

\section{Influence of Informatization on Social Audit}

The impact of information on social auditing is like a double-edged sword, which brings both positive and negative effects.

Positive Impact of Informatization on Social Audits. Applying informatization to social 
auditing can improve the efficiency of social auditing. Firstly, the application of information technology can weaken the space limitation of social auditing and shorten the distance between people and land. Information audit can realize the upload, download and synchronous backup easily between computer documents and memory. The auditor's working papers can synchronous to the server, to the other auditors in the computer simultaneously. It is convenient for the project manager and project partners to consult and review audit work papers. Secondly, the information audit management system provides a guarantee for improving efficiency. Assist audit management with computers, which can give full play to the advantages of high speed and accurate of computer to manage vast amounts of business data and financial data, compiling working paper quickly and efficiently, and completing audit report.

The application of informatization in social auditing can change method of audit and promote the reform of auditing technology. The audit method refers to the general name of the methods, means and techniques adopted by auditors to perform the audit function. The first stage of the evolution of the audit is called the Accounting number-based audit approach. The audit method used is detailed-audit method. The second stage is called system-based audit approach; the audit method used requires a large number of sampling methods. The third stage is called risk-oriented audit whose method is also sampling method. Through the evolution of the audit phase we can see that with the development of the economy, methods of auditing are also changing. The detailed auditing method cannot take the requirements of both quality and efficiency into account, so it evolves into audit sampling. The existence of sampling risk in the audit sampling leads to the limitation of the audit conclusion. Auditors may not be able to discover the major frauds of the audited entity completely. With the advancement of audit informationization, it can be foreseen that the audit informationization will promote the auditing technology change. It can use information technology for audit work such as big data, cloud computing, and artificial intelligence to conduct a comprehensive audit of the data of the audited entity and improve the accuracy of the audit conclusion. The evolution of the audit method is shown in Fig. 1 below.

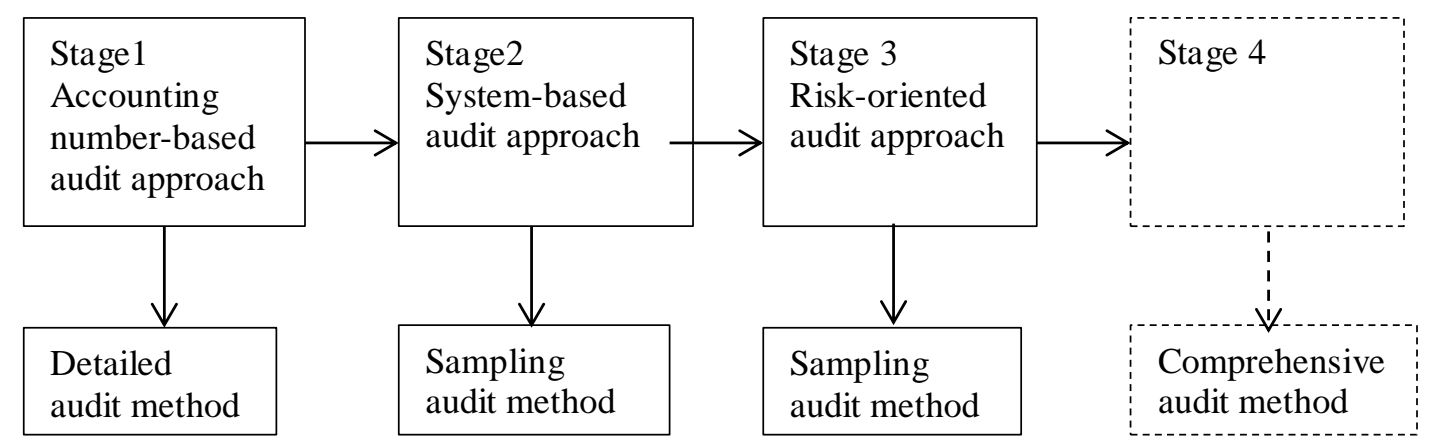

Figure 1. Finite The evolution figure of audit method

Negative Impact of Informatization on Social Audits. In the environment of information, there is a risk of information security in social audits. The accounting information of enterprises is the currency performance of whose economic activities, which involve income, profit and other trade secrets. It may bring incalculable losses to the company if leaked, so the company attaches great importance to its information security construction. There are confidentiality obligations for auditors, who contact the company's business information in the audit process, and they must not provide and disclose externally without approval. However, under the background of informationization, corporate information exists in the form of electronic. Auditing informationization is carried out under the network environment. The virtual nature of the network makes it possible for criminals to attack and stole the company information when auditors upload or download the information involved in audit worksheet.

Information of audit will increase the audit risk for auditors. Because it does not use computer technology in the audit process simply. It emphasizes the organic integration of computer technology and on-site auditing. If auditors are not sophisticated talents proficient in computers and auditing, the audit quality will not be higher than that under manual conditions. However, it is 
possible for social auditors to conduct a comprehensive audit of the audited entity in the context of informatization, which result to a higher expectation of society to social audit. It will bring higher audit risk with the same audit quality under higher social expectations.

\section{Response to the Negative Impact of Informatization on Social Auditing}

The positive impact of audit informationization on social auditing is considered enjoying the fruits of technological progress by social. However, for negative impacts, we should adopt to reduce and eliminate, which can be dealt with in the following ways.

Strengthen Cyber-security Construction. Social audit should strengthen its own network security construction in the process of information construction. There is no uniform standard for audit information systems currently in China. The quality quotient of information systems is uneven, and social auditing can select the giants in the industry as partners, who are responsible for data security maintenance specifically. By paying attention to office system maintenance at the same time, upgrading the office software continuously and emphasizing the security of hardware facilities to build a secure audit environment.

Improve Audit-related System Construction. The method and environment of auditing will change in the age of auditing informatization. There is a need for relevant departments to revise the auditing standards and redefine the responsibilities that social auditors should assume. Auditors who have prudential characteristics commonly will evaluate their own auditing risks during the audit process. If there is no perfect protection of laws and regulations, the promotion of audit informationization is likely to be merely a piece of paper.

Cultivate Sophisticated Talents with Computer Knowledge and Audit. We can cultivate talented personnel with computer knowledge and audit knowledge through the joint efforts of universities, offices, and the community. In the construction of the curriculum system, the auditing profession in universities should build an application-oriented compound personnel training system. Accounting firms should increase the training of those CPAs who have data processing capabilities and information technology background. IT can through continuous training enhance the mastery of information technology for those CPAs who have already engaged in the social audit industry. It is need to focus on audit information for society, and continue to promote the exam of Certified Information System Auditor. At the same time, It is necessary to integrate information technology capability assessment in the CPA exams.

\section{Summary}

With the development of informatization, there is a greater impact for audit informatization on social auditing, which brings both positive and negative effects. In response to the negative effects, we can strengthen the construction of cyber security, improve the audit-related system construction, and cultivate sophisticated talents to deal with.

\section{Acknowledgements}

Research on Practical Teaching Model and Method of Finance Management Major in Applied Undergraduate University (NSUJG2018-007).

\section{References}

[1] Christine E.Earley:Business Horizons, Vol58(2015)No.5,p.493-500.

[2]Nicolás Gambetta,María Antonia García-Benau,Ana Zorio-Grima:Journal of Business Research,Vol69(2016)No.11,p. 4793-4797.

[3] Kimberly D. Westermann; Jean C. Bedard; Christine E. Earley: Contemporary Accounting Research, Vol32 (2015) No.3, p.864-896.

[4]X.J. Wei: 2013 3rd International Conference on Packaging and Manufacturing Technology 
(Brisbane Australia December 31-31, 2013) Vol.1, p.5.

[5]B.G. Chen: 2016 International Conference on Education \& Educational Research and Environmental Studies (Hong Kong China September3-3, 2016) Vol.1, p.5.

[6]Marius Milandru,Daniel Sorin Constantin: International conference KNOWLEDGE-BASED ORGANIZATION,Vol322017)No.2,p.95-100.

[7]H.H. Wang: Commercial Accounting, Vol3 (2015) No.6, p.48-50. (In Chinese)

[8]Z.J. Gu: Modern Accounting, Vol3 (2017) No.12, p.38-41. (In Chinese)

[9]X.X.Ying and L.X.Peng: Research of Finance and Accounting, Vol10 (2017) No.1:27-31. (In Chinese)

[10]Y.S.Wu: Seminar on Audit Full Coverage of Jiangsu Audit Institute (Jiang Su China March 23-23, 2017) Vol.1, p.59-66. (In Chinese) 